\title{
Analysis of Documents Published in Scopus Database on Special Education Learning Through Mobile Learning: A Content Analysis
}

\author{
https://doi.org/10.3991/ijet.v14i22.11732 \\ Zeynep Genç ${ }^{(凶)}$ \\ Istanbul Aydin University, Istanbul, Turkey \\ zeynepgenc1@aydin.edu.tr \\ Alfiya R. Masalimova \\ Kazan (Volga region) Federal University, Kazan, Russia \\ Raisa I. Platonova \\ North-Eastern Federal University, Yakutsk, Russia \\ Zhanna M. Sizova \\ I.M. Sechenov First Moscow State Medical University, Moscow, Russia \\ Olga V. Popova \\ Financial University, Moscow, Russia
}

\begin{abstract}
Special education is one of the educational fields in which technology plays a significant role. Mobile technologies change our lifestyles as well as the way we learn. Mobile learning is the use of mobile technologies alone or in combination with other information and communication technologies to enable learning anywhere, anytime. The purpose of this study is to determine the recent trends in special education through mobile learning. Technology integration studies in the literature generally focus on visual dictionaries, sign language, vocabulary exercises or story books. Besides, it is seen that the studies report the results, not the process. However, there are few studies describing the whole technology integration process with a holistic approach. The study is conducted employing document analysis and related content analysis among the qualitative research methodology. Through the search conducted on Scopus database with the keywords "mobile learning and special education" the study is based on the analysis of the documents published. All articles published in scopus were examined. Their distribution by the years, subject areas, document types, country/regions and the affiliated universities of the authors themes have been examined. The varied findings reveal that the analysis of the studies published on Scopus database is important in terms of content for the significance of special education through mobile learning. Mobile learning method used in special education is among the effective results. However, only a few researches have been conducted.
\end{abstract}

Keywords-Mobile learning, special education, technology, teaching, content analysis 


\section{Introduction}

Education, the development of communication skills and plays an important role in the exercise. One of the most powerful tools in terms of bilateral relations is education, especially in humanitarian relations. Besides, education has a great impact on human nature throughout life [29].

To acknowledge that the decisive effect of education on human life is only related to individuals with normal development, and to ignore individuals with special needs who are part of societies and whose responsibility belongs to all of the society as a whole. Taking advantage of education needs is considered as one of the most natural rights that everyone should have [18].

This right underline that the education and family environment should be arranged in accordance with the development level of these children with the awareness that children with special needs should also have births [9]. It is stated that the education of children with special needs is continuous and this education is closely related to the family members they live with [10].

It is very important to prepare suitable educational environments and programs in order to ensure that special talented individuals are not deprived of the right to education. Children with special abilities cannot be expected to adapt to other children's programs, school settings, curricula, equipment and teachers. Specially gifted children will be able to improve themselves if they are supported by teachers trained in gifted education in specially designed classrooms and programs [4].

Today, many technologies are used in the field of education. As in general education, there are many specially designed tools in the field of special education. The tools and equipment used in the field of special education are known as assistive technology [30]. Assistive technologies are often used by special education teachers who work with students affected by disability. The effective use of assistive technologies by teachers varies depending on their attitudes towards technology. Determining the attitudes of special education teachers towards assistive technologies will contribute to the development of educational services provided to students affected by disability [3] [14] [16]. Mobile learning can be a part of the solution to this resource problem, however, for the technological solution to work, technologies need to be designed and implemented in new ways. Mobile applications used in special education try to help children with special needs to communicate and struggle about even with the most basic of concepts [20].

In the literature, there are different definitions of assistive technology. In the most general sense, assistive technology is defined as any kind of equipment or device specially designed or adapted to facilitate the life skills of the affected individuals, to increase, develop and maintain these skills [5][12][26] [27]. From this definition in mind, a number of auxiliary services and technologies can be said that a comprehensive concept that includes the tools (Murugai and Arulsamy, 2013).

An analysis of research in Turkey on students affected by the failure. There are studies that test the effectiveness of technology applications [25]. As a result of these studies, it has been reported that the use of assistive technologies gives effective results on 
students affected by the inadequacy. In addition to effectiveness researches, the use of assistive technology [2][6] [3][8][25].

The literature review reveals that mobile learning has become a rapidly expanding field of research and practice in many educational institutions, particularly in universities, as a result of the increasing technological capacity of mobile devices that offer advanced opportunities and attract new users with the expansion of wireless networks. Comprehensive theoretical and conceptual frameworks explaining the relationship between the characteristics of rapid and occasional breakthrough technological developments and the roles and educational potentials of users in their daily lives have not yet been found. However, mobile learning is becoming increasingly widespread in both hem formal" and "formal" education and is gaining importance by attracting the attention and attention of practitioners and researchers in all areas of education. National and international conferences, new books and periodicals in which educational practices can be followed to support in-class and / or outside students clearly demonstrate the importance given to mobile technologies in education.

The use of mobile technologies such as iPads for educational purposes might increase the communication opportunities of individuals with developmental and neurological disabilities, increase the awareness and social acceptance of augmented and alternative communication systems, increase the level of adoption and functionalise these technologies [28].

This learning model provides the opportunity to learn anytime, anywhere where mobile technologies are used:

- Individual learning in which learners can determine their learning speed

- Placement of learning in a real context

- Co-operation in which individuals work in groups and help each other

- Informal (non-formal) learning approaches from the formal and non-formal education system (outside the classroom) (Cheon et al., 2012; Naismith \& Corlett, 2006; Traxler Barcena and Laborda, 2015; 8]

Karanfiller, Yurtkan, Ruştioğlu \& Göksu, [17] research Many mobile applications and software are available for teaching, thus this study will point the effect of using such technologies in teaching activities as an assistive method to the teacher. The tests are done using our previously designed mobile application that is designed to teach the basic concepts. As it is indicated in the design, the process starts with the testing of the basic abilities of the children, therefore, our tests include these kind of pretests and after that testing phases that will measure the effect of the application to learning. Students who need special education are the focus of the study. The tests are carried out in a special education centre, in Nicosia, Northern Cyprus on two students. Test results show that the mobile application developed in its current form, is a good tool to assist the teachers to enhance and speed up the learning process.

Ismaili [15] research on mobile use in special education is as follows. Assistive Technology (AT) has revolutionized the learning process for specific needs in the last 30 years. Thanks to this technology, accessibility and participation in education has become more accessible than ever in the history of special education. Meanwhile, assistive technology devices are not accessible to a large number of disabled students, 
especially in the less developed and developing countries of Morocco, especially due to a number of factors, especially availability and affordability. Mobile learning, especially using smartphones and tablets, can offer alternative solutions as special training tools in these countries. In addition, open-source platforms, especially the Google play store, can eliminate the need for single-function, sometimes expensive, AT devices, with all applications available to people with disabilities. This article is designed to explore the potential of using smartphones and tablets as alternative learning tools for assistive technology devices in formal and informal learning environments. Compares seven free Google Play medical apps with seven assistive technology devices at the level of functionality and affordability. Applications are related to cases of physical and mental disability such as hearing impairment, visual impairment, autism and articulation disorders of speech.

Cengel [7] concept teaching based on animation and simulation is intended by making use of technology in the education of mentally retarded students. This process makes a valuable contribution to students in terms of concept learning at schools and rehabilitation centers which facilitate for learning by technology assisted visual programs. This study was conducted with 40 students at four schools of mentally retarded and rehabilitation centers inning Sakarya. The evaluation of the data obtained from the application, students who have been learning the concepts of mobile learning tools revealed that they are more successful than those who had learned classical learning methods. According to these results, it can be said that mobile devices make a contribution to concept learning of mentally retarded students.

There are sample researches which will lead the use of supportive technology such as tablets, smart boards, laptops, cloud technology applications, and teaching robots in special education [19] [24].

When the studies are examined, it is seen that the use of mobile application in special education is effective. Very few researches have been conducted in this area. This research is important in terms of revealing the researches about mobile learning in special education.

The literature review reveals that a few many studies conducted on mobile learning. The purpose of this study is to analyze the research conducted on special education through the method of mobile learning. Under the scope of this general aim; the answers to the following sub-objectives are sought for:

- How are the documents distributed over the years?

- How is the distribution according to subject areas?

- How is the distribution according to document type?

- How is the distribution according to country/regions?

- How is the distribution according to the affiliated universities of the authors?

\subsection{The purpose and importance of the study}

The purpose of this study is to systematically analyze the articles accessed through search on Scopus database with selected keywords by examining according to desig- 
nated themes through discussing with other related basic concepts. Through the research the views regarding the use of mobile learning in special education learning will be evaluated to contribute to further studies in the related subject areas.

\section{Limitations}

- This research is limited to the selected and reviewed documents in the Scopus database

- The research is limited to the documents published between the years 2010 and 2019, accessed through Near East University Scopus database

- The content analysis of the documents is limited to the 5 themes specified above

\section{Methodology}

\subsection{Method}

The study is conducted employing document analysis and related content analysis among the qualitative research methodology. The basic process in content analysis is to compile similar data within the framework of specified concepts and themes and interpret them organizing in a way that readers can understand (Yıldırım and Şimşek, 2006). Content analysis is a scientific frame that allows a systematic analysis of written, verbal and other resources [3]. Cohen, Manion and Morrison (2007) define content analysis as presenting the messages included in the existing documents briefly and succinctly.

\subsection{Data collection and analysis}

Within the scope of the research on foreign language learning through the mobile learning method, primarily a search was conducted on Scopus database using the keywords "mobile learning and special education" between the years 2010 and 2019 and the search yielded 18 documents which are presented in Figure 1. The documents retrieved through the Scopus database are analyzed, integrated by correlation with each other and the data was analyzed through content analysis.

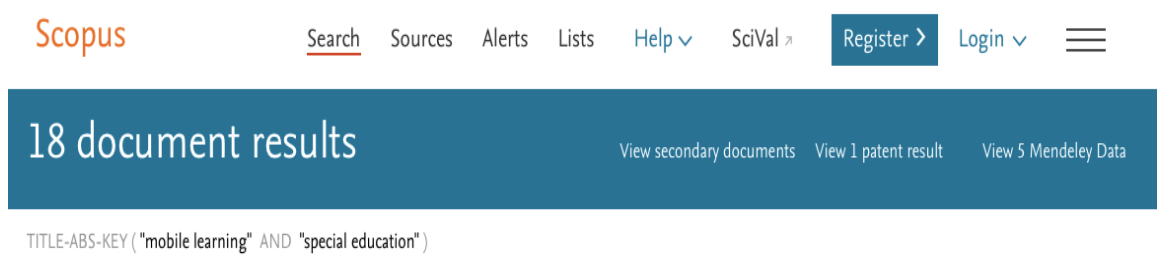

Fig. 1. The documents accessed on Scopus database through keywords "mobile learning and special education" 


\section{$3 \quad$ Findings}

\subsection{The distribution of the documents by the years}

At this stage of the research the distribution of the documents between the years 2010 and 2019 are examined. In this context, 18 studies are accessed through Scopus database, their distribution is presented in Table 1 .

Table 1. Distribution of the Documents by the Years

\begin{tabular}{|c|c|}
\hline Years & Frequency \\
\hline 2019 & 2 \\
\hline 2018 & 1 \\
\hline 2017 & 2 \\
\hline 2016 & 5 \\
\hline 2015 & 2 \\
\hline 2014 & 3 \\
\hline 2013 & 1 \\
\hline 2012 & 0 \\
\hline 2011 & 0 \\
\hline 2010 & 2 \\
\hline
\end{tabular}

When the studies on special education through mobile learning method are analyzed it is revealed that the majority of the studies are conducted between the years of 2010 and 2019 The first study was conducted in 2010; and it is revealed that in 2011 and 2012 there are no studies.

\subsection{Distribution of the documents by subject areas}

Table 2. Distribution of the Documents by Subject Areas

\begin{tabular}{|l|c|}
\hline \multicolumn{1}{|c|}{ Subject Area } & f \\
\hline Social Sciences & 14 \\
\hline Computer Science & 10 \\
\hline Engineering & 6 \\
\hline Mathematics & 4 \\
\hline Energy & 2 \\
\hline Environmental Science & 2 \\
\hline Arts and Humanities & 1 \\
\hline Pharmacology, Toxicology and Pharmaceutics & 1 \\
\hline
\end{tabular}

When the studies on special education through mobile learning method are analyzed it is revealed that most of the studies are conducted on the subject area of Social Science (13) and Computer ESciences (10). It is also revealed the fewest number of studies was conducted on subject area of Arts and Humanities, Pharmacology, Toxicology and Pharmaceutics. 


\subsection{Distribution of the documents by document types}

Table 3. Distribution of the Documents by Document Types

\begin{tabular}{|l|c|}
\hline \multicolumn{1}{|c|}{ Document Type } & F \\
\hline Article & 11 \\
\hline Conference Paper & 3 \\
\hline Review & 2 \\
\hline Book Chapter & 1 \\
\hline Editorial & 1 \\
\hline
\end{tabular}

When the studies on special education through mobile learning method are analyzed it is revealed that the majority of the studies are published as article (11). There is one book chapter and one editorial on special education through mobile learning method.

\subsection{Distribution of the documents by the countries of authors}

Table 4. Distribution of the Documents by the Countries of Authors

\begin{tabular}{|l|c|}
\hline \multicolumn{1}{|c|}{ Country } & f \\
\hline United States & 4 \\
\hline Greece & 3 \\
\hline Malaysia & 3 \\
\hline China & 2 \\
\hline Canada & 1 \\
\hline Cyprus & 1 \\
\hline Morocco & 1 \\
\hline Spain & 1 \\
\hline Taiwan & 1 \\
\hline Turkey & 1 \\
\hline United Kingdom & 1 \\
\hline Total & 32 \\
\hline
\end{tabular}

When the countries of authors of the studies on special education through mobile learning method are analyzed it is revealed that the majority of the studies are conducted in United States (4). There are 1 studies from Turkey, United Kingdom, Taiwan, Spain, Morocco, Cyprus, Canada. 


\subsection{Distribution of the documents by the authors' affiliated universities}

Table 5. Distribution of the Documents by the Authors' Affiliated Universities

\begin{tabular}{|c|c|}
\hline Affiliation & $\mathbf{F}$ \\
\hline Demokritos National Centre for Scientific Research & 3 \\
\hline Beijing Union University & 2 \\
\hline Capital Normal University & 2 \\
\hline Universiti Teknologi Malaysia & 2 \\
\hline American College of Greece & 2 \\
\hline Keuka College & 1 \\
\hline Universidad de Murcia & 1 \\
\hline McGill University & 1 \\
\hline Nottingham Trent University & 1 \\
\hline Old Dominion University & 1 \\
\hline Multimedia University & 1 \\
\hline Institute of Informatics and Telecommunications, Athens & 1 \\
\hline University of Nottingham & 1 \\
\hline University of Toronto & 1 \\
\hline Université Sidi Mohamed Ben Abdellah & 1 \\
\hline Wright State University & 1 \\
\hline Sakarya Üniversitesi & 1 \\
\hline National Applied Research Laboratories Taiwan & 1 \\
\hline University of Texas of the Permian Basin & 1 \\
\hline Universidad de Granada & 1 \\
\hline University of Malaya & 1 \\
\hline Kent State University & 1 \\
\hline York University & 1 \\
\hline Uluslararas1 K1bris Üniversitesi & 1 \\
\hline Faculté des Lettres et des Sciences Humaines Saïs-Fés, Université Sidi Mohamed Ben Abdellah & 1 \\
\hline Total & 18 \\
\hline
\end{tabular}

When the affiliated universities of authors of the studies on special education through mobile learning method are analyzed it is revealed that the author who published the most is affiliated with Demokritos National Centre for Scientific Research.

\section{Conclusion and Discussion}

In the research designed as content analysis that is initiated with the search conducted on Scopus database with the keywords "mobile learning and special education", 5 themes are specified and a total of 18 documents are accessed and the documents are analyzed with regards to the specified themes. According to this, when the distribution of the documents by the years published between the years of 2010 and 2019 is analyzed the studies conducted on special education through mobile learning method increased in time while the highest number of studies, 18, are conducted between the years of 2011 and 2012. It is noticeable that there are no studies conducted. 
Most studies on the use of mobile devices for educational purposes tend to focus on ordinary students with no disabilities [15]. For example, Godwin-Jones [13] examined the ways in which a smartphone or tablet can be used by language learners and the factors that are of increasing interest to such devices. Recently, m-learning experts have become more interested in special needs students. Akpan and Beard [1] outlined assistive technologies that can help teachers improve students' academic outcomes. Murcia, a research team from the University of Granada and the University, launched a mobile platform called Picaa, which is based on iOS, targeting students with special needs and working on iPad and iPod devices [11]. With the increasing number of open source applications, it becomes difficult and confusing to choose the right application that can meet the needs of disabled students. OK et al. [23] came up with a rubric for instructional applications to teach students with learning difficulties. The assessment aims to enable teachers as well as parents to evaluate practices and select the most appropriate for their children's special needs.

When the studies on special education through mobile learning method are analyzed it is revealed that most of the studies are conducted on the subject area of Social Science (14) and Computer Sciences (10). It is also revealed the fewest number of studies was conducted on subject area of Arts and Humanities, Pharmacology, Toxicology and Pharmaceutics.

When the studies conducted on special education through mobile learning method between the years of 2010 and 2019 are analyzed it is revealed that the majority of the studies are published as articles (11). There is one editorial and one book chapters on special education through mobile learning method.

When the countries of authors of the studies on special education through mobile learning method between the years of 2010 and 2019 are analyzed it is revealed that the majority of the studies are conducted in United States (4). This implies that both subjects are given significance in United States. This is 1 study from Canada, Cyprus, Morocco, Spain, Taiwan, Turkey, United Kingdom. This kind of research is needed to increase in Turkey.

When the affiliated universities of authors of the studies on special education through mobile learning method between the years of 2010 and 2019 are analyzed it is revealed that the author who published the most is from Security and Communication Networks.

\section{Acknowledgement}

The work is performed according to the Russian Government Program of Competitive Growth of Kazan Federal University.

The work is performed according to the project of improving competitiveness of the leading Russian universities among the leading world scientific education centers "5100"of First Moscow State Medical University. 


\section{References}

[1] J. Akpan \& L. Beard, "Overview of assistive technology possibilities for teachers to enhance academic outcomes of all students". Universal Journal of Educational Research, 1(2), 113118,2013

[2] I.A. Arı, \& F. A. İnan, “Assistive technologies for students with disabilities: A Survey of access and use in Turkish universities". The Turkish Online Journal of Educational Technology (TOJET), 9(2), 40-45, 2010

[3] C. Aslan, "Özel Eğitim Öğretmenlerinin Yardımcı Teknolojilere Yönelik Tutumları". Eğitim Teknolojisi Kuram ve Uygulama, 8 (1), 102-120, 2018. https://doi.org/10. 17943/etku.319972

[4] Y. Aydoğan, G. Gültekin-Akduman, "Yasa ve Yönetmelikler Işığında Geçmişten Günümüze Özel Yetenekli Çocukların Hakları1". Üstün Zekalılar Eğitimi ve Yaratıcılık Dergisi, 4 (2), 1-11, 2017. Retrieved from http://dergipark.org.tr/jgedc/issue/38702/449423

[5] J. Borg, A. Lindstrom \& S. Larsson, "Assistive technology in developing countries: National and international responsibilities to implement the convention on the rights of persons with disabilities". Lancet, 374(28), 1863-1865, 2009. https://doi.org/10.1016/s0140$\underline{6736(09) 61872-9}$

[6] S. Çakmak, (Ed.), Özel Eğitim ve Yardımcı Teknolojiler. Ankara: Vize Yayıncılık 2016.

[7] M. Çengel, "Concept Teaching to Mentally Retarded Students through Mobile Devices". Online Submission. 2015.

[8] S. Çuhadar, \& M. Kıyıcı, "Zihin engelliler öğretmenliği öğrencilerinin bilgi ve iletişim teknolojilerini kullanma durumları". 7th International Educational Technology Conference, Lefkoşa, KKTC Kongresi'nde Sunulmuş Bildiri. 2007.

[9] İ. H. Diken, "Özel eğitime gereksinimi olan öğrenciler ve özel eğitim". Ankara: Pegem Akademi, 2015. https://doi.org/10.14527/9786055885267

[10] M. Doğan, "Yetersizliği olan çocuklar, aile ve aile eğitimi: kavramsal ve uygulamaya dönük gelişmeler". Abant İzzet Baysal Üniversitesi Eğitim Fakültesi Dergisi, 15(Özel Say1), 111127, 2014. https://doi.org/10.17240/aibuefd.2015.15.0-5000128646

[11] Á., Fernández-López, M. J., Rodríguez-Fórtiz, M. L., Rodríguez-Almendros, \& M. J. Martínez-Segura, "Mobile learning technology based on iOS devices to support students with special education needs". Computers \& Education, 61, 77-9, 2013. https://doi.org/10. 1016/j.compedu.2012.09.014

[12] D., Fok, M., Polgar, L., Shaw, \& J. W. Jutai, "Low vision assistive technology device usage and importance in daily occupations". Work, 39(1), 37-48, 2011.

[13] R. Godwin-Jones, "Emerging technologies: mobile apps for language learning". Language Learning and Technology, 15(2), 2-11, 2011.

[14] H., Hafiar, P., Subekti, \& A. R. Nugraha, "Internet Utilization by the Students with Visual Impairment Disabilities". International Journal of Emerging Technologies in Learning, 14(10), 2019. DOI: 10.3991/ijet. v14i10.10057 https://doi.org/10.3991/ijet.v14i10.10057

[15] J. Ismaili, "Mobile learning as alternative to assistive technology devices for special needs students". Education and Information Technologies, 22(3), 883-899, 2017. https://doi.org/ $\underline{10.1007 / \mathrm{s} 10639-015-9462-9}$

[16] S. Kanbul \& H. Uzunboylu, "Importance of Coding Education and Robotic Applications for Achieving 21st-Century Skills in North Cyprus".International Journal of Emerging Technologies in Learning, 12(1), 2017. https://doi.org/10.3991/ijet.v12i01.6097

[17] T., Karanfiller, K., Yurtkan, O., Ruştioğlu, \& H. Göksu, "Effect of mobile teaching on students who need special education". Quality \& Quantity, 52(2), 1353-1363, 2018. https://doi.org/10.1007/s11135-018-0715-8 
[18] T. Kargın, "Kaynaştırma: Tanımı, gelişimi ve ilkeleri”. Ankara Üniversitesi Eğitim Bilimleri Fakültesi, Özel Eğitim Dergisi, 5(2) 1-13 2004. https://doi.org/10.1501/ozlegt_0000000080

[19] N. Kayhan, \& P. Akmese, "Examining the game teaching in special education teacher training in Turkey and European Union Member States". Cypriot Journal of Educational Sciences, 13(3), 349-359, 2018. https://doi.org/10.18844/cjes.v13i3.751

[20] G. K. Kokkalia, \& A. S. Drigas, "Mobile learning for special preschool education". International Journal of Interactive Mobile Technologies, 10(1), 2016. https://doi.org/10.3991/ ijim.v10i1.5288

[21] F. Levent, "Üstün yetenekli çocukların hakları el kitabı anne baba ve öğretmenler için”. İstanbul: Çocuk Vakfi Yayınları. 2011.

[22] A., Murugaiyan, \& S. Arulsamy, "Attitude of student teachers towards integration of assistive technology in inclusive classrooms". International Journal of Teacher Educational Research (IJTER), 2(4), 1-8, 2013.

[23] M. W. Ok, M. K. Kim, E. Y. Kang, \& B. R. Bryant, "How to find good apps an evaluation rubric for instructional apps for teaching students with learning disabilities." Intervention in School and Clinic, 2015. Doi:105345121558917 https://doi.org/10.1177/10534512155 $\underline{89179}$

[24] F. Ozdamli, "Attitudes and opinions of special education candidate teachers regarding digital technology." World Journal on Educational Technology: Current Issues, 9 (4), 191-200, 2017. https://doi.org/10.18844/wjet.v9i4.2581

[25] C. S., Özgüç \& A. Cavkaytar, "Teacher use of instructional technology in a special education school for students with intellectual disabilities: A case study". Turkish Online Journal of Qualitative Inquiry, 5(1), 51-65, 2014. https://doi.org/10.17569/tojqi.14394

[26] I., Pettersson \& G. Fahlstrom, "Roles of assistive devices for home care staff in Sweden: A qualitative study." Disability and Rehabilitation: Assistive Technology, 5(5), 295-304, 2010. https://doi.org/10.3109/17483100903100285

[27] P., Reed, \& G. Bowser, "Assistive technologyand the IEP. Editors: Edyburn, K. Higgins \& R. Boone." Handbooks of special education technology research and practice (pp. 61- 77). Whitefish Bay, WI: Knowledge by Design, 2005.

[28] I., Sancar, S., Tozkoparan \& H. Odabasi, "Use of mobile technologies in special education: A content analysis." Journal of Education and Special Education Technology, 3(1), 1-12, 2017. https://doi.org/10.18844/jeset.v3i1.3890

[29] H., Soran, B. Akkoyunlu, \& Y. Kavak, "Yaşam boyu öğrenme becerileri ve eğiticilerin eğitimi programı: Hacettepe Üniversitesi örneği.” H.Ü. Eğitim Fakültesi Dergisi, 30, 201210, 2006. https://doi.org/10.17556/erziefd.413425

[30] E. Tekinarslan, \& A. Y1kmış, "Özel eğitim kurumlarında çalışan öğretmenlerin teknoloji kullanımına yönelik görüşleri ve beklentileri.” Abant İzzet Baysal Üniversitesi Sosyal Bilimler Enstitüsü Dergisi, 2(11), 211-220, 2005. https://doi.org/10.11616/abantsbe.151

\section{$7 \quad$ Authors}

Zeynep Genç is a member of the Istanbul Aydin University, Faculty of Education, Department of Special Education, Istanbul, Turkey E-mail: zeynepgenc1@aydin.edu.tr

Alfiya R. Masalimova is a member of the Institute of Psychology and Education, Kazan (Volga region) Federal University, Kazan, Russia. E-mail: alfkazan@mail.ru https://orcid.org/0000-0003-3711-2527 
Raisa I. Platonova is member of the Faculty of Road Construction, North-Eastern Federal University named after M.K. Ammosov, Yakutsk, Russia. E-mail: platonovaraisa@mail.ru

Zhanna M. Sizova is member of the department of Urgent and Outpatient Therapy, I.M. Sechenov First Moscow State Medical University (Sechenov University), Moscow, Russia. E-mail: sizova-klinfarma@mail.ru

Olga V. Popova works with Financial University under the Government of the Russian Federation (49 Leningradsky prospect, 125993, Moscow, Russia). She has more than 50 published scientific works in Russian and international journals, indexed by Scopus and Web of Science data bases. Her research interests are connected with educational environment problems, educational technologies and economic effectiveness of educational system.

Article submitted 2019-09-23. Resubmitted 2019-10-23. Final acceptance 2019-10-25. Final version published as submitted by the authors. 